\title{
A SURVEY STUDY TO DETECT PROBLEMS ON SALTED HIDES AND
} SKINS

\author{
PINAR CAGLAYAN ${ }^{1}$, MERAL BIRBIR $^{1}$, ANTONIO VENTOSA $^{2}$ \\ ${ }^{1}$ Marmara University, Faculty of Arts and Sciences, Biology Department, Istanbul,Turkey, \\ pinar.caglayan@marmara.edu.tr \\ ${ }^{2}$ University of Sevilla, Pharmacy Faculty, Microbiology and Parasitology Department, Spain
}

\begin{abstract}
Some problems originated from raw hides/skins can not be recovered by other steps in leather processing and affect adversely quality of leather. To detect these problems, a questionnaire containing 14 questions was prepared and applied to 15 leather technicians working in different tanneries of Tuzla and Corlu Leather Industrial Zones, Turkey. According to questionnaire results, numbers of tanneries used cattle hides were higher than those of goat and sheep skins. Hides/skins cured in different countries were used in leather industry. Storage period of salted hides/skins was not long and most of samples were processed between one and six months. Storage temperature of tanneries were ranged from $0 \mathrm{oC}$ to $30^{\circ} \mathrm{C}$. Dry salting was used mostly by tanneries. Fairly high percentage of tanneries used only salt in preservation of hides/skins. Problems such as hair loosening, bacterial and fungal growth, bad odor, red heat, holes, stains on hides/skins and loss of hide/skin elasticity were reported by technicians. Most of problems encountered in leather industry were related to bacterial and fungal growth and their activities. Our microbiological studies results supported that presence of red heat, bad odor, hair slip, stains, holes on the hides/skins and loss of leather elasticity was closely related to microbial growth and activities.
\end{abstract}

Keywords: Leather industry, tanneries, questionnaire

\section{INTRODUCTION}

Raw hides and skins, which are the most valuable by-product of meat industry, are cured with salt after the animal is slaughtered (Vankar and Dwivedi, 2009). As known, animals contain normal flora of microorganisms and contaminant microorganisms found in the air, soil, water, animal feeds, dust, barn, pasture and feces (Birbir and Ilgaz, 1996; Birbir et al., 2016; Oppong et al., 2006). When the animal is alive, most of these microorganisms have little effect on hides and skins, but after flaying process these microorganisms use proteins, fats and carbohydrates to grow rapidly and digest hide and skin substances. Traditionally, sodium chloride is used for preservation of animal hides and skins as a curing agent which is routinely applied in leather industry (Vankar and Dwivedi, 2009). In this method, fresh hides and skins are cured with 40-50\% concentration of sodium chloride, and the moisture content of hides and skins is reduced to $40-48 \%$ (Bienkiewickz, 1983; Kanagaraj et al., 2001; Bailey, 2003). Although salt is used for curing process, the experimental results of other investigations showed that it contaminates hides and skins with halotolerant microorganisms, slightly halophilic bacteria, moderately halophilic bacteria, extremely halophilic archaea and fungi. The salt samples obtained from Sereflikochisar Salt Lake, which is used in leather industry for curing hides and skins, were examined by Birbir et al. (2002). The researchers determined diverse halophilic bacterial and archaeal communities in the curing salt (Birbir et al., 2002). In the study of Berber et al. (2010), archaeal and bacterial populations were detected on curing salt samples, salted hides, soaked hides, soaking liquors. In another study, various Gram-positive and Gram-negative bacterial species were isolated from salted hides by Aslan and Birbir (2011, 2012). Moreover, moderately halophilic bacteria and extremely halophilic archaea were isolated from salted sheep and goat skins by the researchers (Akpolat et al., 2015; Caglayan et al., 
2015). In addition to bacterial species, fungal species were detected in the curing salt samples collected from Tuz Lake. Experimental results showed that preservation salt samples contained different fungal species (Ozyaral and Birbir, 2005). While bacterial and archaeal species may cause cream, yellow, white, pink, red discolorations, slimy layer, bad odor, hair slip, pin pricks, entire degradation of hair follicle, holes in grain surface, grain peeling, distruption of collagen fibers on the salted hides and skins (Anderson, 1954; Haines, 1984; Kallenberger, 1985; Birbir and Ilgaz, 1996; Berber and Birbir, 2010; Aslan and Birbir, 2011; Akpolat et al., 2015), fungal species may cause yellow, green, white, black discolorations, unpleasant musty odors, surface roughness, loss of physical and mechanical resistance on salted hides and chrome-tanned hides (Birbir et al.,1994; Karaboz et al., 2003; Fontoura et al., 2016).

Although there are several studies about the microorganisms and their adverse effects on the leather quality, there is no information about the quality problems of hides and skins and the factors affecting leather mentioned by leather technicians. Hence, the goal of the study was to collect data on the problems encountered in leather industry from the leather technicians.

\section{MATERIAL AND METHODS}

The questionnaire containing 14 questions was applied to leather technicians working in 15 different tanneries found in tanneries in Tuzla and Corlu Leather Industrial Zones, Turkey in 2015. Eight tanneries in Tuzla and seven tanneries in Corlu participated in the following questionnaire:

1.Which type of animal hides/skins do you process?

2.Do you process imported leather?

3.How long do you store the hides/skins before tanning process?

4.What is the storage temperature of hides/skins?

5.Which method do you use to preserve raw hides/skins?

6.Where do you get salt used in the preservation of hides/skins?

7.Do you utilize the used salt again?

8.Do you use antimicrobials during the curing of hides/skins? If you use, could you please write the names and content of antimicrobial?

9.Do you apply the salting method to the hides/skins or do you buy salted hides/skins?

10.How much salt do you use in salting process? $(\mathrm{kg} /$ per skin)

11.What are the defects observed on the salted hides/skins?

12.How long does it take for effective curing process of hides/skins?

13.Have you noticed bad odor in the stacked salted hides/skins?

14. What are the other issues that are not included in this survey?

\section{RESULTS AND DISCUSSION}

According to questionnaire results, only sheep skins, goat skins or cattle hides, both cattle hides and goat/sheep skins, both sheep and goat skins are processed by the Turkish tanneries (Figure 1). Questionnaire results indicated that the numbers of tanneries used cattle hides were higher than those of goat and sheep skins. These raw materials were belong to Australia, Bulgaria, Israel, South Africa, Russia, China, Turkey, France, Greece, U.S.A., Dubai, and Kuwait. Fifty-three percent, 27\%, 20\% of 
the tanneries processed imported, domestic, both domestic and imported hides/skins, respectively.

Storage periods of salted hides/skins were not long. According to questionnaire results, $46.6 \%, 6.7 \%, 33.3 \%, 6.7 \%, 6.7 \%$ of the tanneries stored salted hides/skins at one month, 1-3 months, 3-6 months, 6-12 months, more than 12 months, respectively. More than half of the tanneries stored salted hides/skins more than one month. When the storage period is longer, the microorganisms can grow and the microbial damage can be more worse.

Storage temperatures of the hides/skins were between $0-10^{\circ} \mathrm{C}, 10-20^{\circ} \mathrm{C}, 20-30^{\circ} \mathrm{C}$ for $33.3 \%, 46.6 \%, 6.7 \%$ of the tanneries, respectively. Two tanneries $(13.4 \%)$ could not give a definite answer about the storage temperature. It was reported that the moderately halophilic bacteria isolated from salted skins and hides could be able to grow $4-45^{\circ} \mathrm{C}$ (optimally $37^{\circ} \mathrm{C}$ ) (Birbir et al., 2015; Caglayan, 2015). In addition fungi can grow at room temperatures. To prevent microbial growth and damage, salted hides/skins should be stored at $5^{\circ} \mathrm{C}$.

While $86.6 \%$ of the tanneries apply salt curing method, $13.4 \%$ of the tanneries apply brine curing method. As known, most of the hides/skins cured in different countries were processed in Turkey. However, all Turkish hides/skins were cured using salt obtained from Tuz Lake. It was determined that most of the tanneries (93\%) used only salt for curing process, one tannery (7\%) used the mixture of boric acid and salt in curing process. In the tanneries, $1-12 \mathrm{~kg}$ of salt were used per skin and hide during curing process. This amount varied according to the size and type of the animal. Raw salt obtained from salt lake and salterns contain microorganisms. In the study carried out with 40 curing salt samples, archaeal counts were found as between $10^{2}-10^{4} \mathrm{CFU} / \mathrm{g}$ (Berber and Birbir, 2010). In that study, proteolytic and lipolytic extremely halophilic archaea were detected in the most salt samples. Therefore, the preservation salts should be treated with antimicrobial applications.

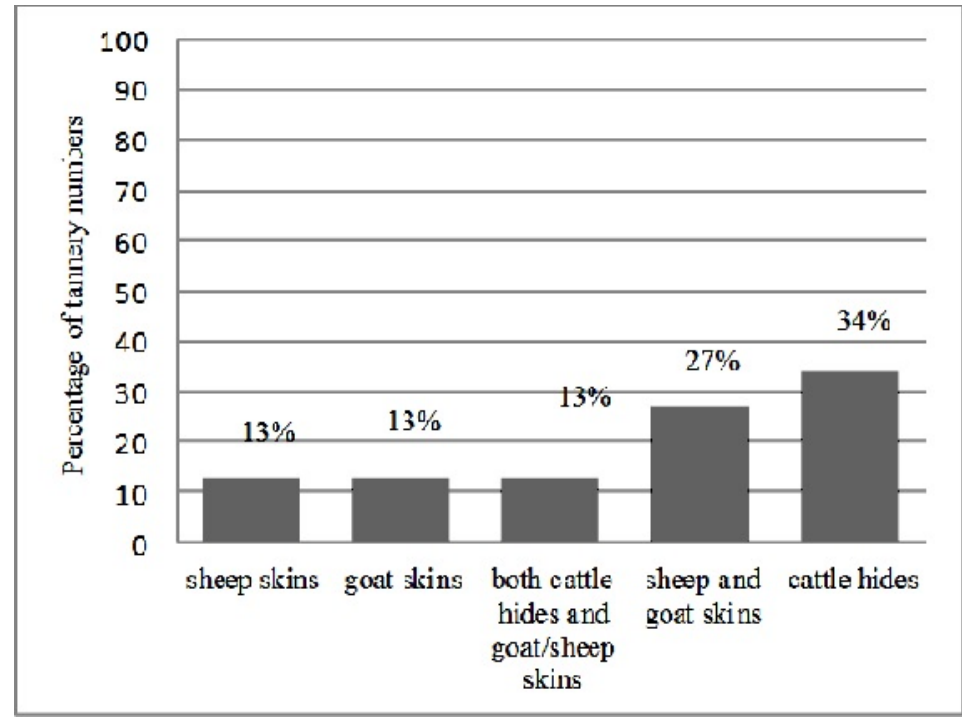

Figure 1. Types of hides and skins processed 
Leather technicians emphasized that red heat, bad odor, hair slip, stains, loss of leather elasticity, holes, bacterial, fungal growth, staining differences were among the important problems observed on the hides and skins. We think that these problems were closely correlated with the previous studies' results. In the study of Berber and Birbir (2010), the bacterial counts were found as $10^{2}-10^{6} \mathrm{CFU} / \mathrm{g}$ in 36 salted hides collected from different tanneries in Tuzla, Turkey. It was also stated that proteolytic and lipolytic extremely halophilic archaea were observed in salted hides. In addition, the numbers of proteolytic and lipolytic extremely halophilic archaea were respectively $10^{2}-10^{6} \mathrm{CFU} / \mathrm{g}$, on the salted hides (Berber and Birbir, 2010). In our study carried out with 25 salt-cured sheep skins and 25 salt-cured goat skins, non-halophilic bacteria $\left(10^{3}-10^{7} ; 10^{3}-10^{7}\right.$ $\mathrm{CFU} / \mathrm{g})$, moderately halophilic bacteria $\left(10^{3}-10^{7} ; 10^{3}-10^{7} \mathrm{CFU} / \mathrm{g}\right)$ and extremely halophilic archaea $\left(10^{3}-10^{7} ; 10^{4}-10^{7} \mathrm{CFU} / \mathrm{g}\right)$ were isolated from the samples. Proteolytic non-halophilic bacteria $\left(10^{2}-10^{6} ; 10^{2}-10^{6} \mathrm{CFU} / \mathrm{g}\right)$, proteolytic moderately halophilic bacteria $\left(10^{2}-10^{6} ; 10^{2}-10^{6} \mathrm{CFU} / \mathrm{g}\right)$ and proteolytic extremely halophilic archaea $\left(10^{2}-10^{6}\right.$; $10^{2}-10^{6} \mathrm{CFU} / \mathrm{g}$ ) were detected on all salted sheep and goat skins. Moreover, we found lipolytic non-halophilic bacteria $\left(10^{2}-10^{6} ; 10^{2}-10^{6} \mathrm{CFU} / \mathrm{g}\right)$, lipolytic moderately halophilic bacteria $\left(10^{2}-10^{6} ; 10^{2}-10^{6} \mathrm{CFU} / \mathrm{g}\right)$ and lipolytic extremely halophilic archaea $\left(10^{2}-10^{6} ; 10^{2}-10^{6} \mathrm{CFU} / \mathrm{g}\right)$ on both salted sheep and goat skins (Caglayan et al., 2018). These isolates were white, cream, pink, yellow pigmented. The growth of these bacteria may cause stains on the hide/skin surface. Moreover, extremely halophilic archaea produce red, orange and pink coloured colonies due to the presence of C50 carotenoids (Akpolat et al., 2015). It is known that the growth of extremely halophilic archaea cause red discolorations on the salted hides and skins (Grant et al., 2001). Furthermore, the hides/skins were preserved with curing salt for one month, three months, 6 months, more than six months by $33.3 \%, 33.3 \%, 20 \%, 13.4 \%$ of the tanneries, respectively.

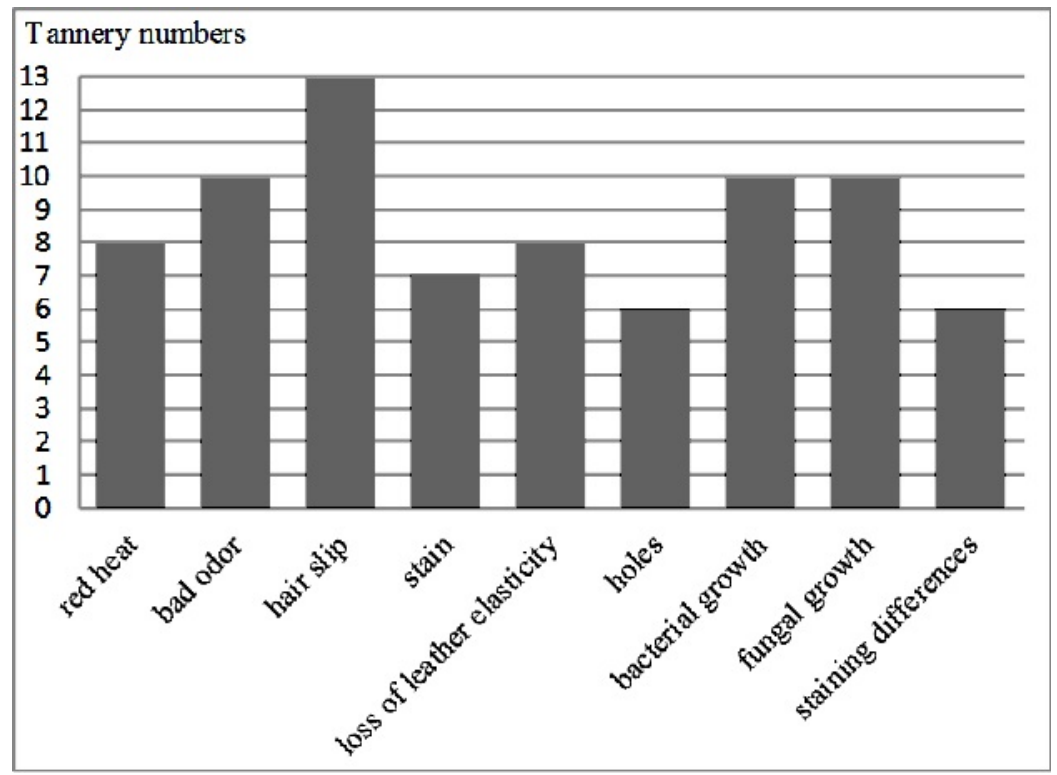

Figure 2. The problems encountered in the tanneries 
When we combine our experimental results with the results of questionnaires applied to leather technicians, we concluded that the aforementioned problems may be caused as a result of metabolic activities of proteolytic and lipolytic bacterial and archaeal microorganisms found on the hides and skins.

\section{CONCLUSIONS}

Our survey study results showed that most of the problems encountered in the leather industry were related to microbial activities. Our microbiological studies' results supported that presence of red heat, bad odor, hair slip, stains, loss of leather elasticity, holes on the hides/skins were closely related to microbial growth and activities. Most of tannery technicians reported that bacterial and fungal growth were also common problems on the hides/skins. Hence, the storage temperature should be decreased to prevent microbial growth.

\section{REFERENCES}

Akpolat, C. et al. (2015), "Molecular Identification of Moderately Halophilic Bacteria and Extremely Halophilic Archaea Isolated from Salted Sheep Skins Containing Red and Yellow Discoloratios", The Journal of the American Leather Chemists Association, 110, 211-220.

Anderson, H. (1954), "The Reddening of Salted Hides and Fish", Applied and Environmental Microbiology, 2, 64-69.

Aslan, E. and Birbir, M. (2011), "Examination of Gram-Positive Bacteria on Salt-Pack Cured Hides", The Journal of the American Leather Chemists Association, 12(106), 372-380.

Aslan, E. and Birbir, M. (2012), "Examination of Gram-Negative Bacteria on Salt-Pack Cured Hides", The Journal of the American Leather Chemists Association, 4(107), 106-115.

Bailey, D.G. (2003), "The Preservation of Hides and Skins", The Journal of the American Leather Chemists Association, 98, 308-319.

Berber, D., Birbir, M. and Mertoğlu, B. (2010), "Examination of Bacterial and Archaeal Populations in Salt, Salted and Soaked Hide and Soak Liquors via Fluorescent In Situ Hybridization”, Journal of the Society of Leather Technologists and Chemists, 6(94), 259-261.

Berber, D. and Birbir, M. (2010), "Examination of Bacterial Populations in Salt, Salted Hides, Soaked Hides and Soak Liquors", The Journal of the American Leather Chemists Association, 105, 320-326.

Bienkiewickz, K. (1983), "Physical Chemistry of Leather Manufacture", Florida, Krieger Publishing Company, Volume 33.

Birbir, M. et al. (1994), "Mold Strains Isolated from Unfinished and Finished Leather Goods and Shoes", The Journal of the American Leather Chemists Association, 89, 14-19.

Birbir, M. and Ilgaz, A. (1996), "Isolation and Identification of Bacteria Adversely Affecting Hide and Leather Quality", Journal of the Society of Leather Technologists and Chemists, 80, 147-153.

Birbir, M., Kalli, N. and Johansson, C. (2002), "The Examination of Salt Quality of Şereflikoçhisar Lake Used in Turkish Leather Industry", Journal of the Society of Leather Technologists and Chemists, 86(3), 112-117.

Birbir, M., Ventosa, A. and Caglayan, P. (2015), "Characterization of Moderately Halophilic Bacteria Found on the Sheep and Goat Skins", The Scientific Research Project Commission of Marmara University, Project number FEN-C-DRP-040712-0281.

Birbir, M., Ulusoy, K. and Caglayan, P. (2016), "Examination of Multidrug resistant Enterobacteriaceae Isolated from Salted Cattle Hides and Sheep Skins", Journal of the American Leather Chemists Association, 111, 334-344.

Caglayan, P. (2015), "Characterization of Moderately Halophilic Bacteria Found on the Sheep and Goat Skins", PhD Thesis, Marmara University.

Caglayan, P. et al. (2015), "Characterization of Moderately Halophilic Bacteria from the Salt-pack Cured Hides", Journal of the Society of Leather Technologists and Chemists, 5, 250-254.

Caglayan, P. et al. (2018), "Investigation of Moderately Halophilic Bacteria Causing Deterioration of the Salted Sheep and Goat Skins and Their Extermination via Electric Current Applications", Journal of the American Leather Chemists Association, 113, 41-52.

Fontoura, J.T., Ody, D. and Gutteres, M. (2016), "Performance of Antimicrobial Agents for the Preservation of Chrome Leather", The Journal of the American Leather Chemists Association, 111(6), 221-229.

https://doi.org/10.24264/icams-2018.VIII.4 
Grant, W.D. et al. (2001), "Phylum All. Euryarchaeota phy. nov., Class III. Halobacteria, Order I. Halobacteriales", in Bergey's Manual of Systematic Bacteriology: The Archaea and the Deeply Branching and Phototrophic Bacteria, 2nd Edn., eds. D. R. Boone, R. W. Castenholz and G. M. Garrity, Springer-Verlag, New York, USA, 2001, Vol. 1, 294-333.

Haines, M.B. (1984), "Quality Rawstock", The Journal of the American Leather Chemists Association, 66, 164-173.

Kallenberger, W.E. (1985), "Halophilic Bacteria in Hide Curing”, Ph.D. Thesis, Division of Graduate Studies and Research of the University of Cincinati, Department of Basic Science Tanning Research of The Collage of Arts and Science.

Kanagaraj, J. et al. (2001), "Cleaner Techniques for the Preservation of Raw Goat Skins", Journal of Cleaner Production, 9, 261-268, https://doi.org/10.1016/S0959-6526(00)00060-3.

Karaboz, I., Gülümser, G. and Bayramoğlu Eke, E. (2003), “Tabakhanelerde Depolama Sırasında Gelişen Bazı Fungusların Koruma Piklesi ve Kromla Tabaklama Aşamasında Deride Oluşturdukları Pigmentasyonun İncelenmesi”, Ege Üniversitesi Ziraat Fakültesi Dergisi, 40(3), 129-136.

Oppong, D. et al. (2006), "Application of Molecular Techniques to Identify Bacteria Isolated From the Leather Industry", The Journal of the American Leather Chemists Association, 101, 140-145.

Ozyaral, O. and Birbir, M. (2005). "Examination of the Fungal Community on Salt Used in the Turkish Leather Industry", Journal of the Society of Leather Technologists and Chemists, 89, 237-241.

Vankar, P.S. and Dwivedi, A.K. (2009), "Raw Skin Preservation Through Sodium Salts-A Comparative Analysis", Desalination, 249, 158-162, https://doi.org/10.1016/j.desal.2008.08.011. 